\title{
POTENSI PENGEMBANGAN MASOYI (Cryptocarya massoy (Oken) Kosterm) DI WILAYAH UPTD KPH UNIT V BOALEMO BERDASARKAN KESIAPAN MASYARAKAT DAN TINGKAT KESESUAIAN LAHAN
}

\author{
(Potency of masoyi plantations in the area of UPTD KPH Boalemo Gorontalo Unit V \\ based on community readinness and land suitability)
}

\author{
Irma Yeny, Budi Hadi Narendra dan/and Hani Siti Nuroniah \\ Pusat Penelitian dan Pengembangan Hutan \\ J1. Gunung Batu No. 5 Po Box 165 Bogor, Jawa Barat, Indonesia \\ Telp. 0251-8633234; Fax 0251-8638111 \\ E-mail: irmayeny.kemenhut@yahoo.com; budihadin@yahoo.co.id; nuronish@yahoo.com
}

Tanggal diterima: 27 September 2018; Tanggal direvisi: 19 November 2018;

Tanggal disetujui; 20 November 2018

\begin{abstract}
Plantations development in KPH UPTD Boalemo Unit V area should be supported by community readiness and land suitability. This study analyzed the potential of masoyi plantations in the UPTD KPH Boalemo Gorontalo Unit $V$ based on community readiness and land suitability. The level of community readiness was measured through in-depth interviews with key informants. Land suitability analysis was carried out using species matching method on the plant growth requirements of masoyi. Land characteristics were obtained from secondary data, direct field measurements, and soil analysis. The results showed: 1) community readiness is at level seven to nine; Ayuhulalo Village, Bendungan Village, Botumoito Village, and Rumbia Village have the highest community readiness, 2) land suitability is divided into: suitable 15.93\%, moderately suitable 53.82\%, and 24\% unsuitable, 3) an area of 22,644 ha have the potential for development of masoyi plantation because it has a high level of community readiness and land suitabiliy level at moderately suitable, 4) an area of 7,041 ha is a priority area for the development of masoyi because it has a high level of community readiness and land suitability class at suitable, 5) Bendungan Village and Butomoito Village have the best community readiness and land suitability, 6) production forest area is dominated by marginally suitable land; land improvement/ manipulation is needed towards the limiting factors to support successful planting.
\end{abstract}

Key words: Masoyi, land suitability, growing requirements, plantations

\begin{abstract}
ABSTRAK
Upaya pengembangan hutan tanaman di wilayah UPTD KPH Unit V Boalemo perlu didukung kesiapan masyarakat dan kesesuaian lahan. Penelitian ini menganalisis potensi pengembangan masoyi di wilayah UPTD KPH Unit V Boalemo Gorontalo berdasarkan kesiapan masyarakat dan kesesuaian lahannya. Tingkat kesiapan masyarakat diukur melalui wawancara mendalam terhadap tokoh-tokoh kunci. Analisis kesesuaian lahan dilakukan menggunakan metode pencocokan (species matching) terhadap persyaratan tumbuh tanaman masoyi. Karakteristik lahan diperoleh melalui pengumpulan data sekunder, pengukuran langsung di lapangan, dan analisis tanah di laboratorium. Hasil penelitian menunjukkan: 1) kesiapan masyarakat berada pada level tujuh sampai dengan sembilan; empat desa yaitu Desa Ayuhulalo, Desa Bendungan, Desa Botumoito, dan Desa Rumbia memiliki kesiapan lahan level sembilan (rasa memiliki di tingkat masyarakat tinggi), 2) kesesuaian lahan terdiri atas $15,93 \%$ sesuai, 53,82\% agak sesuai, dan 30,24\% tidak sesuai, 3) wilayah dengan luas 22.644 ha berpeluang bagi pengembangan masoyi karena memiliki tingkat kesiapan masyarakat yang tinggi (level 7 sampai 9) dan memiliki kelas kesesuaian agak sesuai, 4) wilayah dengan luas 7.041 ha merupakan lahan prioritas bagi pengembangan masoyi karena memiliki tingkat kesiapan masyarakat tinggi (level 7 sampai 9) dan memiliki kelas kesesuaian lahan sesuai, 5) desa dengan tingkat kesiapan masyarakat terbaik dan kesesuaian lahan pada kriteria sesuai adalah Desa Bendungan dan Desa Butomoito, 6) kawasan hutan produksi didominasi tingkat kesesuaian lahan agak sesuai sehingga perlu adanya perbaikan/manipulasi lahan terhadap faktor pembatas guna mendukung keberhasilan penanaman.
\end{abstract}

Kata kunci: Masoyi, kesesuaian lahan, persyaratan tumbuh, hutan tanaman 


\section{PENDAHULUAN}

Unit Pelaksana Teknis Daerah Kesatuan Pengelolaan Hutan (UPTD $\mathrm{KPH})$ Unit V Boalemo merupakan salah satu KPH di Propinsi Gorontalo. UPT tersebut menjalankan visi Dinas Kehutanan dan Pertambangan Provinsi Gorontalo yaitu, "Terwujudnya sistem pengelolaan hutan yang berkelanjutan, berwawasan lingkungan dan didukung oleh aparatur profesional guna mendukung kesejahteraan rakyat Gorontalo. Visi tersebut dijabarkan melalui salah satu misinya yaitu mengoptimalkan sumberdaya alam menuju kemandirian dan menetapkan program utama sektor kehutanan diantaranya: "Program pemantapan pemanfaatan sumberdaya hutan", yang salah satu kegiatan pokoknya adalah pembangunan kesatuan unit-unit manajemen pengelolaan hutan, meliputi KPH untuk memberikan kepastian kawasan hutan.

Pengembangan KPH Boalemo menuju sistem pengelolaan hutan yang berkelanjutan terkendala oleh rendahnya pendapatan masyarakat, perambahan lahan untuk kebun jagung dan pembalakan liar (UPTD KPH Unit V Boalemo, 2015). Untuk mengatasi permasalahan tersebut, telah disusun rencana pengelolaan kawasan UPTD KPH Unit V Boalemo yang salah satunya bertujuan untuk meningkatkan kesejahtaraan rakyat melalui pemanfaatan hasil hutan bukan kayu (HHBK) pada hutan alam. Dalam rencana pengelolaan kawasan, ditetapkan areal pemanfaatan HHBK seluas \pm 18.558 ha, yang terdiri dari pemanfaatan HHBK rotan seluas \pm 11.000 ha dan HHBK damar seluas \pm 7.558 ha. Di samping itu ditetapkan pula rencana pemanfaatan hasil hutan bukan kayu hutan tanaman (HHBKHT) seluas \pm 2.049 ha yang terdiri dari pengembangan HHBK masoyi \pm 300 ha, HHBK-HT karet \pm 1.000 ha, HHBK-HT jernang seluas \pm 700 ha dan HHBK-HT kakao seluas \pm 49 ha (UPTD KPH Unit V Boalemo, 2015).

Masoyi (Cryptocarya massoy
(Oken) Kosterm) merupakan tanaman berkayu endemik Papua (Rostiwati \& Efendi, 2013). Tanaman masoyi menghasilkan minyak atsiri dengan senyawa aktif yang dikenal dengan nama lactone. Minyak masoyi diperoleh dari proses ekstraksi kulit batang (Suminar, Arifin, \& Kemala, 2015) yang pada umumnya dipanen dengan cara menebang pada pohon yang berumur $>10$ tahun. Ekstrak etilasetat dari kulit kayu masoyi menunjukkan tingkat toksisitas yang sangat tinggi dan nilai $\mathrm{IC}_{50}$ sebesar 44,02 ppm yaitu sebagai antioksidan kuat (Bustanussalam, Haryanto, \& Endang, 2014). Berdasarkan Permenhut 35/2007 tentang Hasil hutan bukan kayu (HHBK) disebutkan bahwa tanaman masoyi merupakan komoditi HHBK yang menjadi urusan Departemen Kehutanan. Pemanfaatan minyak masoyi pada umunya sebagai bahan makanan dan jamu, obat sakit perut dan cacing, serta perisa makanan (flavor), kosmetik, dan obat penenang (Rostiwati, \& Efendi, 2013).

Kebutuhan masoyi dunia mencapai $500 \mathrm{ribu}$ ton/tahun, sedangkan Indonesia mampu memproduksi 8-12 ribu ton/tahun (Suminar, et al., 2015). Umumnya minyak masoyi diekspor ke Eropa, Amerika, Jepang, India, dan Cina. Suplai minyak masoyi sampai saat ini berasal dari Papua dan PNG. Terbatasnya wilayah yang mampu menyuplai kulit masoyi menyebabkan semakin tingginya harga penjualan kulit masoyi. Harga jual online kulit kayu masoyi tahun 2017 berkisar Rp 120.000 - 250.000/kg semen-tara di tingkat petani Rp 60.000- $75.000 / \mathrm{kg}$ (Yeny, \& Minarningsih, 2018).

Tingginya permintaan minyak masoyi menyebabkan beberapa pengusaha minyak atsiri melakukan upaya pengembangan tanaman masoyi diluar habitat alami seperti di Sumatera, Kalimantan, dan Jawa Barat (Yeny, \& Minarningsih, 2018). Sejalan dengan rencana pengelolaan kawasan, UPTD $\mathrm{KPH}$ Unit V Boalemo juga melakukan 
pengembangan masoyi sebagai upaya memanfaatkan kawasan hutan untuk meningkatkan produktivitas lahan dan kesejahteraan masyarakat. Uji coba pengembangan masoyi telah dilakukan sejak tahun 2014, namun mengalami kegagalan. Hasil evaluasi menunjukkan bahwa kegagalan disebabkan adanya ketidaksiapan petani dan faktor ketidaksesuaian lahan. Kondisi ini menunjukkan bahwa terdapat permasalahan terkait sumberdaya manusia dan sumberdaya lahan dalam pengembangan masoyi. Oleh karena itu dibutuhkan perencanaan yang tepat dalam mengembangkan tanaman masoyi dengan mempertimbangkan faktor kesiapan masyarakat dan kesesuaian lahan untuk tanaman masoyi.

Dalam permasalahan pengembangan komoditi di suatu wilayah, kesiapan masyarakat dapat digambarkan sebagai interaksi sosial yang merupakan bagian dari ilmu sosiologi. Analisis sosiologi yang dilakukan pada aspek kesiapan masyarakat merupakan suatu upaya untuk memahami realitas kehidupan masyarakat. Kesiapan masyarakat merupakan kondisi yang menunjukkan sejauh mana respon masyarakat terhadap implementasi suatu program/kebijakan. Apabila masyarakat belum siap, maka program pembangunan akan berpotensi mengalami kegagalan. Sebaliknya jika, masyarakat sudah siap, maka program pembangunan akan lebih mudah dilaksanakan dan memberikan manfaat.

Evaluasi kesesuaian lahan pada hakekatnya merupakan prosedur dalam penentuan kualitas suatu lahan untuk tujuan penggunaan tertentu (Elsheikh, Shariff, Amiri, Ahmad, Balasundram, \& Soom, 2013). Metode evaluasi kesesuaian lahan kini berkembang dengan melibatkan analisis yang berbasis keruangan (spasial). Pada analisis ini, Geographical Information System (GIS) sangat berperan dalam menganalisis data spasial secara fleksibel dan akurat (Mokarram, \& Aminzadeh, 2010). Evaluasi kesesuaian lahan dilakukan dengan terlebih dahulu menganalisis persyaratan tumbuh yang mengacu pada habitat alami masoyi di Papua secara spasial yang selanjutnya akan menghasilkan peta yang menggambarkan potensi penggunaan lahan. Evaluasi kesesuaian lahan secara spasial akan menghasilkan peta yang menggambarkan potensi penggunaan lahan untuk produktifitas tanaman yang optimal (Pan, \& Pan, 2012), serta dapat mencegah terjadinya degradasi lingkungan (Elaalem, Comber, \& Fisher, 2011; Kazemi, \& Akinci 2018).

Penelitian ini bertujuan untuk mengetahui sebaran lokasi yang tepat bagi pengembangan masoyi di wilayah UPTD $\mathrm{KPH}$ Unit $\mathrm{V}$ Boalemo berdasarkan kondisi kesiapan masyarakat desa dan kesesuaian lahan. Hasil penelitian diharapkan dapat digunakan untuk menghindari kegagalan pengembangan masoyi dan menghemat sumber daya dengan pemilihan wilayah yang memiliki peluang keberhasilan paling tinggi di UPTD KPH Unit V Boalemo.

\section{METODOLOGI}

\section{A. Waktu dan Tempat Penelitian}

Penelitian dilakukan pada tahun 2015 di dua lokasi yaitu : 1) pengumpulan data kesiapan masyarakat dilakukan di UPTD KPH Unit V Boalemo Kabupaten Boalemo Propinsi Gorontalo, 2) pengumpulan data persyaratan tumbuh masoyi sebagai dasar analisis kesesuaian lahan dilakukan di Kampung Kaprus Distrik Tahota Kabupaten Manokwari, Papua Barat.

\section{B. Metode}

Untuk menganalisis diperlukan data/informasi berupa kuesioner hasil wawancara guna mengukur kesiapan masyarakat dan mengevaluasi lahan. Untuk mengevaluasi lahan digunakan data/informasi berupa: 1) peta tata guna lahan Sulawesi dan Papua, 2) peta 
topografi digital, dan 3) peta sebaran curah hujan UPTD KPH Unit V Boalemo.

\section{Pengumpulan data kesiapan masyarakat}

Pengukuran kesiapan masyarakat dilakukan melalui wawancara dan studi pustaka terhadap dokumen rencana pengelolaan UPTD KPH Unit V Boalemo. Wawancara dilakukan untuk memvalidasi data yang sebelumnya telah diperoleh dari berbagai pustaka khususnya terhadap data hasil survei potensi sumberdaya hutan dan sosial ekonomi. Validasi data dilakukan dengan bantuan kuesioner terhadap empat orang responden kunci yang dilakukan secara purposif yaitu: Kepala UPTD KPH
Unit V Boalemo, Kepala Desa Ayululalo, Kepala Desa Bendungan, dan Kepala Desa Dulangenya. Pada tujuh desa lainnya validasi data dilakukan melalui wawancara dengan Kepala UPTD KPH Unit V Boalemo untuk mengkonfirmasi data dan informasi tentang kondisi sosial ekonomi masyarakat yang ada dalam dokumen rencana pengelolaan UPTD KPH Unit V Boalemo. Pengukuran kesiapan masyarakat dilakukan dengan menggunakan konsep model kesiapan masyarakat yang dikembangkan oleh Plested, Edwards, \& Jumper (2006) yaitu model kesiapan masyarakat terbagi atas sembilan level (Tabel 1).

Tabel (Table) 1. Tahapan kesiapan masyarakat (Level of community readiness)

\begin{tabular}{|c|c|}
\hline Tahap (Level) & Deskripsi (Description) \\
\hline $\begin{array}{l}\text { 1. Tidak ada kesadaran } \\
\text { (No awareness) }\end{array}$ & $\begin{array}{l}\text { Masyarakat atau kelompok masyarakat secara umum belum } \\
\text { menyadari isu yang berkembang merupakan sebuah masalah } \\
\text { yang harus dipecahkan (Communities or community groups do } \\
\text { not realize that the issue must be solved by community } \\
\text { empowerment) }\end{array}$ \\
\hline $\begin{array}{l}\text { 2. Perlawanan } \\
\text { (Denial/resistance) }\end{array}$ & $\begin{array}{l}\text { Hanya sedikit masyarakat yang sudah menyadari isu tersebut, } \\
\text { sementara masyarakat umumnya masih cenderung apatis (Few } \\
\text { people are aware of the issue, while most people tends to be } \\
\text { apathetic) }\end{array}$ \\
\hline $\begin{array}{l}\text { 3. Kesadaran yang } \\
\text { samar (Vague } \\
\text { awareness) }\end{array}$ & $\begin{array}{l}\text { Sebagian besar masyarakat sudah menyadari isu yang } \\
\text { berkembang dan perlunya dilakukan sesuatu untuk mengatasi } \\
\text { isu tersebut. Namun belum ada motivasi untuk menyelesaikan } \\
\text { masalah tersebut. Belum muncul jiwa kepemimpinan untuk } \\
\text { mengarahkan pemecahan masalah (Most people are aware of } \\
\text { the issue and the need to address it. But there is no motivation } \\
\text { and leadership to solve the problem) }\end{array}$ \\
\hline $\begin{array}{l}\text { 4. Perencanaan awal } \\
\text { (Preplanning) }\end{array}$ & $\begin{array}{l}\text { Sudah ada pemahaman bahwa terdapat masalah yang harus } \\
\text { dipecahkan bersama-sama, telah ada figur pemimpin } \\
\text { komunitas namun belum ada perencanaan yang konkrit (There } \\
\text { is an understanding that the problem must be solved together; } \\
\text { there is a community leader but no concrete planning) }\end{array}$ \\
\hline
\end{tabular}


Potensi Pengembangan Masoyi (Cryptocarya massoy (Oken) Kosterm) di wilayah UPTD KPH Unit V Boalemo Berdasarkan Kesiapan Masyarakat dan Tingkat Kesesuaian Lahan

Irma Yeny, Budi Hadi Narendra dan Hani Siti Nuroniah

Tabel (Table) 1. Lanjutan (Continued)

\begin{tabular}{|c|c|}
\hline Tahap (Level) & Deskripsi (Description) \\
\hline $\begin{array}{l}\text { 5. Persiapan awal } \\
\text { (Preparation) }\end{array}$ & $\begin{array}{l}\text { Sudah ada informasi umum tentang isu yang dihadapi, } \\
\text { terdapat pro dan kontra di komunitas, telah terdapat aksi } \\
\text { dan kebijakan yang diambil namun belum berdasarkan } \\
\text { pada data yang akurat. Pemimpin komunitas sudah aktif } \\
\text { mengarahkan pengalokasian sumber daya (SDM, } \\
\text { keuangan, waktu, ruang, dll) (General information about } \\
\text { the issues exists, there are pros and cons in the community, } \\
\text { actions and policies have been taken but not based on } \\
\text { accurate data) (Community leaders actively managed the } \\
\text { resources (human, finance, time, space etc.)) }\end{array}$ \\
\hline 6. Inisiasi (Initiation) & $\begin{array}{l}\text { Komunitas sudah mulai terlibat secara aktif dan sudah } \\
\text { tidak ada resistensi. Sudah dilakukan pelatihan-pelatihan } \\
\text { dan informasi yang mendukung sudah tersedia (The } \\
\text { community is actively involved and there is no resistance. } \\
\text { Training and information are available) }\end{array}$ \\
\hline 7. Stabilitasi (Stabilization) & $\begin{array}{l}\text { Program, kegiatan, dan kebijakan sudah baku. Telah } \\
\text { terbentuk komunitas yang terlatih dan berpengalaman. } \\
\text { Masih sedikit presepsi untuk mengubah atau memperluas } \\
\text { upaya penanganan. Belum ada program evaluasi terhadap } \\
\text { efektivitas program (Programs, activities, and policies are } \\
\text { standardized. A trained and experienced community has } \\
\text { formed. There is little perception to change or expand } \\
\text { handling efforts. There is no evaluation program on } \\
\text { program effectiveness) }\end{array}$ \\
\hline $\begin{array}{l}\text { 8. Konfirmasi/perluasan } \\
\text { (Confirmation } \\
\text { lexpansion) }\end{array}$ & $\begin{array}{l}\text { Masyarakat sudah nyaman dengan hasil yang dicapai, } \\
\text { sudah dilakukan evaluasi dan modifikasi program untuk } \\
\text { memperluas cakupan komunitas, isu-isu atau kelompok } \\
\text { sosial lainnya serta untuk pengembangan program (The } \\
\text { community is comfortable with the results achieved, the } \\
\text { program has been evaluated and modified to expand the } \\
\text { scope of the community, issues or other social groups and } \\
\text { for program development) }\end{array}$ \\
\hline $\begin{array}{l}\text { 9. Rasa memiliki di tingkat } \\
\text { masyarakat tinggi (High } \\
\text { level of community } \\
\text { ownership) }\end{array}$ & $\begin{array}{l}\text { Target group penanganan sudah spesifik, komunitas } \\
\text { terlatih sudah berjalan, evaluasi yang efektif dalam } \\
\text { memperbaiki dan mengembangkan program sudah } \\
\text { berjalan (Target group handlings are specific, the trained } \\
\text { community has been running, an effective evaluation in } \\
\text { improving and developing the program is already } \\
\text { underway) }\end{array}$ \\
\hline
\end{tabular}

Sumber (Source): Plested et al. (2006)

Berdasarkan deskripsi dari setiap level kemudian disusun kuesioner yang mengacu pada tiga konsep operasionalisasi kesiapan masyarakat yang diacu oleh
Wijaya, \& Wiryawan, (2013). Tiga konsep operasionalisasi tersebut meliputi: 1) individu, 2) komunitas, dan 3) delivery system (Tabel 2). 
Tabel (Table) 2. Variabel kesiapan masyarakat (Variable of community readiness)

\begin{tabular}{|c|c|c|c|}
\hline \multirow{7}{*}{ 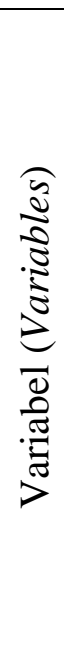 } & \multicolumn{3}{|c|}{ Operasionalisasi konsep (Concept operationally) } \\
\hline & $\begin{array}{l}\text { Individu } \\
\text { (Individu) }\end{array}$ & Komunitas (Community) & $\begin{array}{c}\text { Cara penyampaian } \\
\text { (Delivery system) }\end{array}$ \\
\hline & $\begin{array}{l}\text { Pengetahuan } \\
\text { (Knowledge) }\end{array}$ & $\begin{array}{l}\text { Kearifan Lokal (Local } \\
\text { wisdom) }\end{array}$ & Jaringan dukungan (Net working) \\
\hline & $\begin{array}{l}\text { Presepsi } \\
\text { (Perception) }\end{array}$ & Sumber daya (Resource) & $\begin{array}{l}\text { Ketersediaan informasi (Information } \\
\text { availability) }\end{array}$ \\
\hline & $\begin{array}{l}\text { Motivasi } \\
\text { (Motivation) }\end{array}$ & $\begin{array}{l}\text { Rencana aksi bersama } \\
\text { (Communal action) }\end{array}$ & $\begin{array}{l}\text { Simpul komunikasi (Communication } \\
\text { node) }\end{array}$ \\
\hline & & $\begin{array}{l}\text { Kepemimpinan } \\
\text { (Leadership) }\end{array}$ & $\begin{array}{l}\text { Program dukungan dan kebijakan } \\
\text { (Supporting programmes and policy) }\end{array}$ \\
\hline & & $\begin{array}{l}\text { Forum komunitas } \\
\text { (Institutional community) }\end{array}$ & $\begin{array}{l}\text { Manfaat teknologi (Technology } \\
\text { benefit) }\end{array}$ \\
\hline
\end{tabular}

Sumber (Source): Wijaya, \& Wiryawan, (2013)

\section{Evaluasi kesesuian lahan}

Evaluasi kesesuaian lahan menggunakan metode matching yaitu mencocokkan antara persyaratan ekologis tanaman (agro-ecological requirement) masoyi terhadap karakteristik tiap unit lahan yang meliputi kondisi tanah, iklim, dan topografi (Kawy \& El-Magd, 2012; Rhebergen, Fairhurst, Zingore, Fisher, Oberthür, \& Whitbread, 2016).

Informasi persyaratan tumbuh jenis masoyi masih sangat terbatas, sehingga pada penelitian ini analisis kesesuaian lahan didahului dengan menyusun kriteria persyaratan tumbuh tanaman masoyi. Kriteria disusun oleh penulis melalui analisis kondisi tempat tumbuh yang ada di Kabupaten Manokwari, pengambilan dan analisis sampel tanah, dilengkapi dengan informasi hasil penelitian terdahulu tentang karakteristik sebaran masoyi di Kabupaten Teluk Bintuni dan Kabupaten Nabire (Asmoro, 2016) serta dari literatur tentang sebaran ekologi masoyi lainnya. Keseluruhan informasi tersebut dirangkum untuk menjadi kriteria sementara persyaratan tumbuh tanaman masoyi. Koreksi dilakukan melalui verifikasi lapangan dan diskusi dengan pakar, sebelum akhirnya ditetapkan menjadi persyaratan tempat tumbuh tanaman masoyi.
Karakteristik lahan di KPH Boalemo diidentifikasi berdasarkan peta sistem lahan, peta curah hujan, survei lapangan, dan analisis sampel tanah. Selanjutnya dilakukan analisis spasial berupa tumpang susun (overlay) terhadap seluruh variabel karakteristik lahan untuk menghasilkan sebuah peta unit lahan (Gambar 1).

\section{Analisis data}

Analisis terhadap data kesiapan masyarakat dilakukan dengan memvalidasi data terhadap responden kunci pada sepuluh desa yang berada di dalam dan sekitar kawan hutan dengan menggunakan nilai 1 dan 2. Nilai 1 untuk jawaban tidak dan nilai 2 untuk jawaban ya. Nilai selanjutnya dirata-rata sehingga diperoleh skor kesiapan masyarakat (Tabel 3). Skor yang diperoleh menjadi gambaran kesiapan masyarakat dalam pengembangan masoyi di UPTD KPH Unit V Boalemo.

Analisis kesesuaian lahan terhadap jenis masoyi dilakukan menggunakan data persyaratan tumbuh masoyi dan karakteristik tiap unit lahan secara tabular dan spasial dengan bantuan program GIS yang pada komputer dengan perangkat lunak ArcGIS 10. Pencocokan data atribut dari tiap unit lahan dengan data per- 
syaratan tempat tumbuh masoyi yang terdiri dari 10 variabel dilakukan dengan bantuan fasilitas field calculator pada ArcGIS 10 (Law, \& Collins, 2015). Masing-masing variabel akan dinilai dengan skor 0 sampai 2 ( $0=$ tidak sesuai, $1=$ agak sesuai dan $2=$ sesuai).

Suatu unit lahan dikategorikan "tidak sesuai" untuk jenis masoyi, jika salah satu atau beberapa variabelnya memiliki skor nol. Selanjutnya, unit lahan lainnya akan diklasifikasikan berdasarkan total skor yang diperoleh menjadi tiga kelas yaitu sesuai, agak sesuai, dan tidak sesuai. Hasil analisis ini dituangkan dalam bentuk peta yang menunjukkan distribusi tingkat kesesuaian tanaman masoyi pada hutan produksi dengan informasi tambahan berupa tabulasi luasan masingmasing tingkat kesesuaian dalam wilayah UPTD KPH unit V Boalemo.

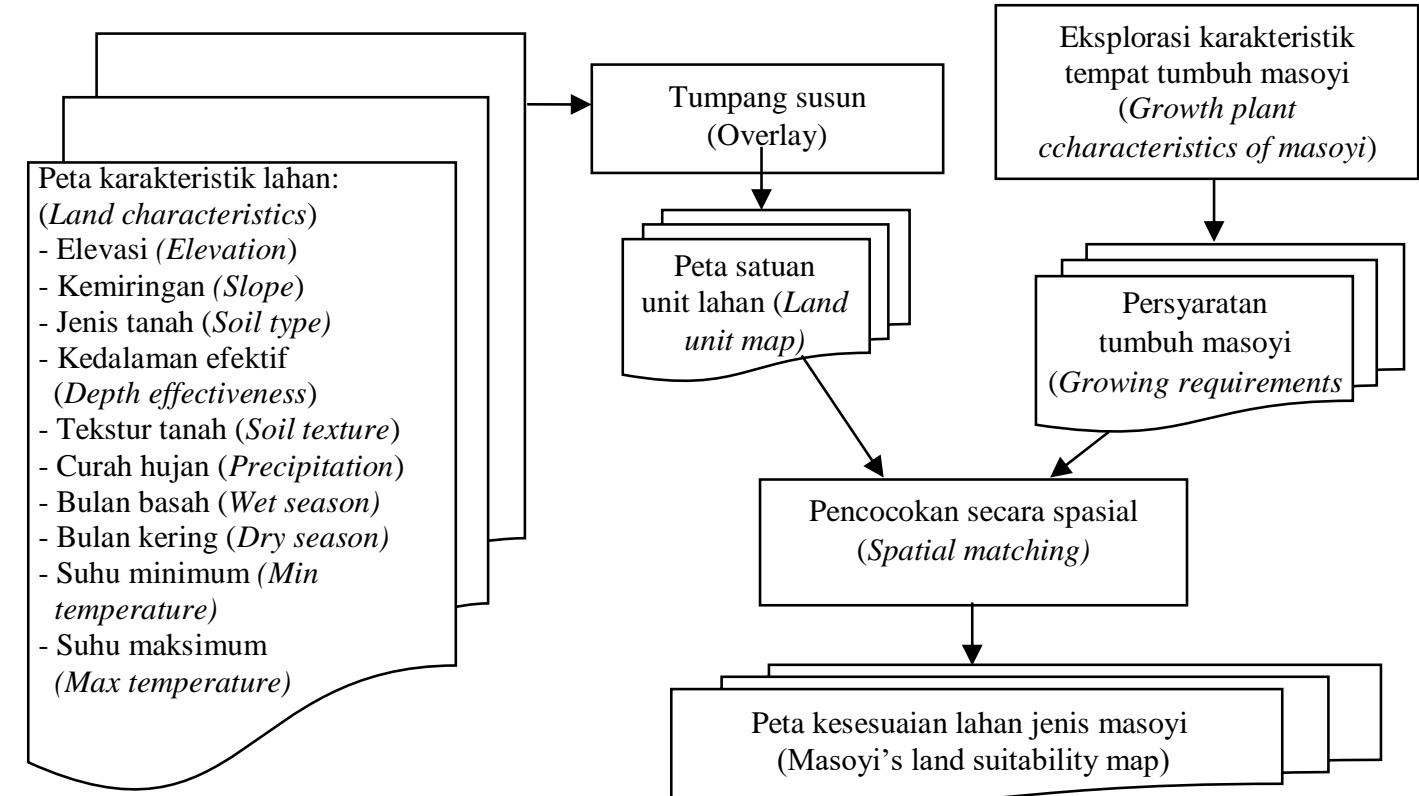

Gambar (Figure) 1. Alur kerja analisis kesesuaian lahan (Flowchart of land suitability analisys)

Tabel (Table) 3. Rentang skor tingkat kesiapan masyarakat (Score range of community readiness level)

\begin{tabular}{lc}
\hline \multicolumn{1}{c}{ Level (Level) } & Rentang skor (Score range) \\
\hline 1. Tidak ada kesadaran (No awareness) & $1,0-1,9$ \\
2. Perlawanan (Denial/resistance) & $2,0-2,9$ \\
3. Kesadaran yang samar (Vague awareness) & $3,0-3,9$ \\
4. Perencanaan awal (Preplanning) & $4,0-4,9$ \\
5. Persiapan awal.(Preparation) & $5,0-5,9$ \\
6. Inisiasi (Initiation) & $6,0-6,9$ \\
7. Stabilitasi (Stabilization) & $7,0-7,9$ \\
8. Konfirmasi/perluasan (Confirmation/expansion) & $8,0-8,9$ \\
9. Rasa memiliki di tingkat masyarakat tinggi (High & $9,0-10$ \\
level of community ownership) & \\
\hline
\end{tabular}

Sumber (Source): Plested et al. (2006) 
Hasil pengukuran kesiapan masyarakat akan diintegrasikan dengan hasil analisis kesesuaian lahan masoyi membentuk suatu wilayah potensial bagi pengembangan masoyi. Wilayah potensial tersebut akan menjadi bahan pertimbangan bagi para perencanaan kawasan di UPTD KPH Unit V Boalemo dalam mengembangkan masoyi dengan melibatkan masyarakat.

\section{HASIL DAN PEMBAHASAN}

A. Hasil

1. Kawasan hutan dan sosial ekonomi masyarakat di UPTD Unit V Boalemo

UPTD Unit $\mathrm{V}$ Boalemo memiliki luas $\pm 87.235,74$ ha yang terdiri dari : Hutan Lindung (HL) $\pm 28.649,75$ ha, Hutan Produksi Terbatas (HPT) \pm 44.088,67 ha, Hutan Produksi Tetap (HP) $\pm 14.497,32$ ha dan Areal Penggunaan Lain (APL) seluas $\pm 9.690,26$ ha. Lokasi wilayah UPTD KPH Unit V Boalemo dapat dilihat pada Gambar 2.

Dalam dokumen rencana pengelolaan disebutkan bahwa wilayah UPTD KPH Unit V Boalemo dalam rencana tata kelola wilayah dibagi ke dalam tujuh blok. Pembagian blok dilakukan dengan menggunakan kesamaan karakteristik biofisik dan sosial budaya yang ditetapkan untuk meningkatkan efektivitas dan efesiensi manajemen. Faktor biofisik yang digunakan sebagai dasar penentuan blok yaitu tutupan lahan, potensi sumberdaya hutan, topografi dan ekosistem. Faktor sosial budaya berupa jumlah penduduk, mata pencaharian, pemilikan lahan, jarak pemukiman, pola pemanfaatan hutan oleh masyarakat dan keberdaaan hutan adat. Pembagian blok dilakukan pada hutan produksi, hutan lindung dan kawasan hutan konservasi. Adapun pembagian blok pada tata hutan UPTD Unit V Boalemo dapat dilihat pada Gambar 2 dan Tabel 4.
Berdasarkan pembagian blok (Tabel 4), pengembangan masoyi dapat dilakukan pada blok pemanfaatan kawasan jasa lingkungan dan HHBK serta blok pemanfaatan hutan kayu untuk hutan alam dan blok pemberdayaan masyarakat. Namun ketersediaan lahan pada masingmasing blok tidak secara langsung dapat diamanfaatkan bagi budidaya masoyi karena dibutuhkan pengelola lahan, yaitu masyarakat yang memiliki ketergantungan terhadap kawasan hutan, sehingga nantinya dapat mengelola blok pemberdayaan dengan optimal.

Kawasan hutan UPTD Unit V Boalemo secara administratif masuk pada wilayah delapan kecamatan dengan 37 desa. Terdapat sepuluh desa yang telah diinventarisasi kondisi sosial ekonominya yaitu: Desa Ayuhulalo, Desa Piloliyanga, Desa Buti, Desa Bendungan, Desa Botumoito, Desa Rumbia, Desa Dulangeya, Desa Hutamonu, Desa Tangkobu dan Desa Tangga Barito. Desa dengan wilayah terluas yaitu Desa Bendungan (244,24 $\mathrm{km}^{2}$ ), dan terkecil Desa Tangkobu (5,72 $\mathrm{km}^{2}$ ). Desa dengan kepadatan penduduk tertinggi adalah Desa Tongkobu (307 jiwa $/ \mathrm{km}^{2}$ ), kepadatan terendah adalah Desa Bendungan (8 jiwa $/ \mathrm{km}^{2}$ ) (UPTD KPH Unit V Boalemo, 2015).

Kegiatan ekonomi masyarakat di desa lokasi inventarisasi mayoritas bermata pencarian utama sebagai petani jagung dan mata pencaharian sampingan sebagai pemungut hasil hutan (penarik kayu, memungut rotan, mencari daun woka, dan membuat gula aren). Pola pengusahaan lahan sebagian besar merupakan warisan orang tua, menyewa, membeli, serta membuka lahan di hutan dengan luas antara 0,4 - 4 ha. UPTD KPH Unit V Boalemo (2015) melaporkan tingkat pendapatan perkapita masyarakat dari sektor usahatani berkisar $\mathrm{Rp}$ 1.004.490 - 3.880.130/tahun, sedangkan pendapatan perkapita masyarakat dari sektor non usahatani berkisar antara $\mathrm{Rp}$ 842,867 - 5.442.952/tahun. Pendapatan 
perkapita masyarakat pada pekerjaan usahatani tertinggi di Desa Hutamonu dan terendah di Desa Ayuhulalo, sedangkan pendapatan perkapita masyarakat dari pekerjaan non usahatani (pemungutan hasil hutan) tertinggi pada masyarakat Desa Tangga Barito dan terendah di Desa Tangkobu. Hal ini mengindikasikan bahwa pendapatan masyarakat dari pekerjaan pemungutan hasil hutan (menarik kayu, mengambil rotan, mencari daun woka, dan membuat gula aren) lebih tinggi dibandingkan dengan pendapatan masyarakat dari berusaha tani. Dengan demikian, kawasan hutan masih menjadi sumber pendapatan terbesar bagi masyarakat sekitar kawasan. Tingginya kegiatan pemungutan hasil hutan menunjukkan adanya ketergantungan masyarakat pada kawasan UPTD Unit V Boalemo. Berdasarkan kondisi tersebut, maka ketersediaan lahan pada blok peman-faatan kawasan jasa lingkungan dan HHBK serta blok pemanfaatann hutan kayu untuk hutan alam dan blok pemberdayaan masyarakat dapat dikelola bersama masyarakat.

Tabel 5 menunjukkan habitat alami masoyi berada pada rentang kemiringan lereng yang cukup besar yaitu 2-60\% dan curah hujan $>1.300 \mathrm{~mm} /$ tahun. Hal ini menunjukkan bahwa masoyi dapat beradaptasi pada kemiringan dan curah hujan yang besar, namun memiliki rentang yang sempit dalam hal elevasi, jenis tanah, tekstur tanah dan kedalaman efektif.

Kriteria persyaratan tumbuh masoyi disajikan pada tabel 6 berdasarkan hasil eksplorasi lapangan pada sebaran alami masoyi di Papua, dan dilengkapi dengan hasil studi pustaka.

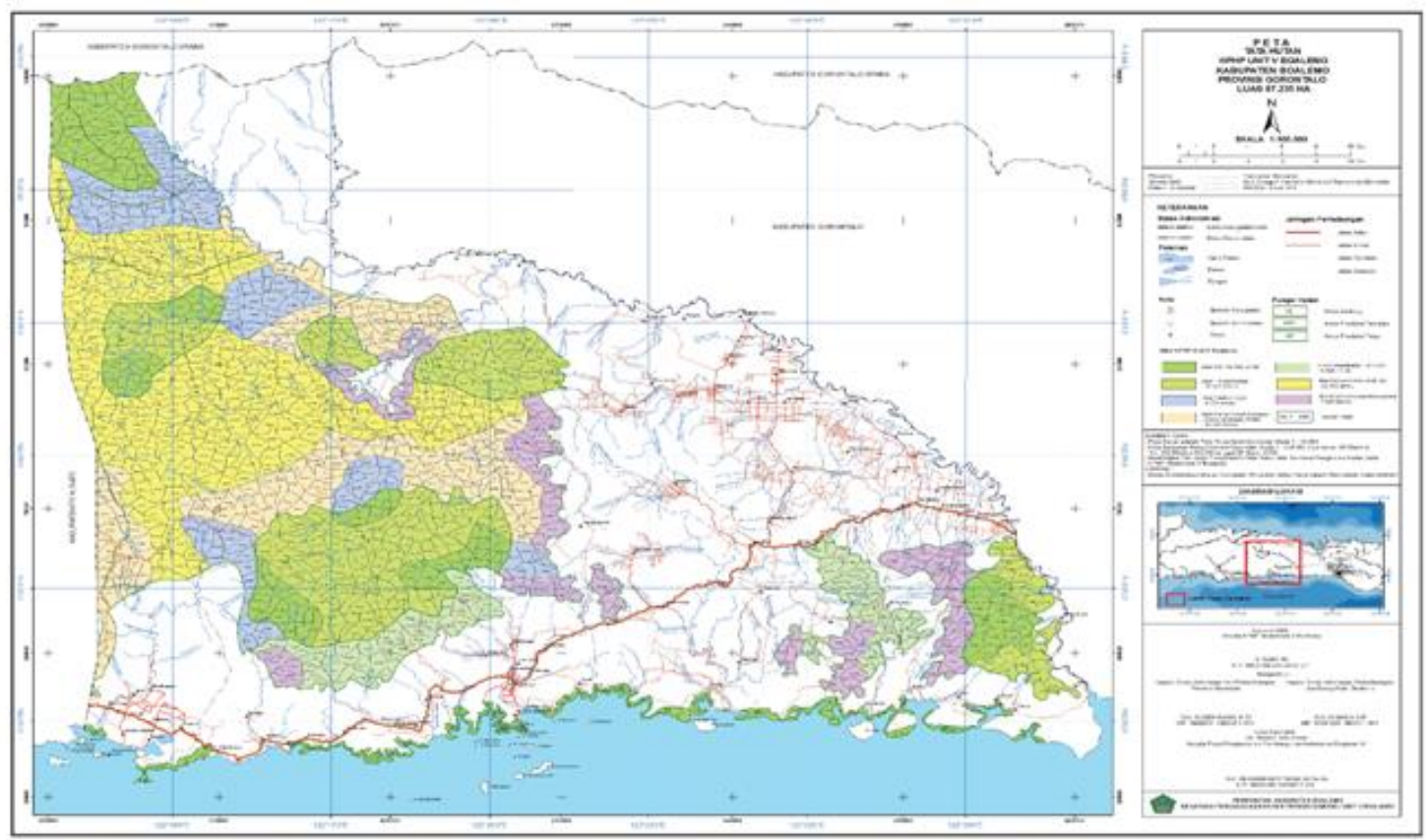

Gambar (Figure) 2. Wilayah KPHP model unit V Boalemo (Area of KPHP model unit V Boalemo) 
Tabel (Table) 4. Pembagian blok dan luas pada UPTD Unit V Boalemo (Block distribution and area of UPTD Unit V Boalemo)

\begin{tabular}{lc}
\hline \multicolumn{1}{c}{ Nama blok (block name) } & Luas (Area) (ha) \\
\hline Blok inti (Main block) & $12.164,56$ \\
Blok perlindungan (Shelter block) & $8.722,44$ \\
Blok pemanfaatan HL (Utilization block-protected forest) & $16.485,19$ \\
$\begin{array}{l}\text { Blok pemanfaatan kawasan, jasa lingkungan, HHBK } \\
\text { (Utilization zone, environmental services, NTFP block) }\end{array}$ & $13.327,41$ \\
$\begin{array}{l}\text { Blok pemanfaatan HHK-HA (Utilization block-TFP's natural } \\
\text { forest) }\end{array}$ & $22.789,45$ \\
$\begin{array}{l}\text { Blok pemanfaatan HHK-HT(Utilization block-TFP's } \\
\text { plantation forest) }\end{array}$ & $6.049,13$ \\
$\begin{array}{l}\text { Blok pemberdayaan masyarakat (Community empowerment } \\
\text { block) }\end{array}$ & $7.697,56$ \\
\hline \multicolumn{1}{c}{ Total } & $87.235,74$ \\
\hline
\end{tabular}

Sumber (Source): UPTD KPH Unit V Boalemo, (2015)

Keterangan (Remaks): HL= Hutan Lindung (Protected Forest); HHK-HA: Hasil hutan kayu hutan alam (Timber forest product from natural forest) : HHK-HT: Hasil hutan kayu hutan tanaman (Timber forest product from plantation forest)

\section{Analisis potensi pengembangan masoyi di UPTD KPH Unit V Boalemo}

\section{a. Kesiapan masyarakat}

Pengukuran kesiapan masyarakat dilakukan pada sepuluh desa yang berbatasan langsung terhadap kawasan $\mathrm{KPH}$ dan memiliki aktifitas masyarakat terhadap kawasan yang cukup tinggi. Hasil pengukuran tersebut menunjukkan perbedaan level kesiapan masyarakat pada masing-masing desa (Tabel. 7).

Tabel 7 menunjukkan bahwa sepuluh desa yang dievaluasi kesiapan masyarakatnya menunjukkan tingkatan level mulai dari level 7 (stabilitasi) sampai dengan level 9 (rasa memilki di tingkat masyarakat tinggi). Kondisi ini menunjukkan bahwa individu dan komunitas pada sepuluh desa tersebut memiliki pengetahuan yang baik terhadap informasi umum isu degradasi lahan, kebijakan pengelolaan KPH, dan pengenalan tanaman masoyi. Masyarakat juga telah dilibatkan dalam pengelolaan hutan, sehingga tidak ada resistensi dalam kebijakan pengelolaan lahan. Pengetahuan ini juga didukung dengan presepsi, motivasi, sumberdaya, kepemimpinan serta dukungan pihak lain yang terdapat pada level individu dan komunitas. Desa dengan tingkat kesiapan yang paling tinggi level 9 (rasa memilki di tingkat masyarakat tinggi) adalah Desa Bendungan, Desa Ayuhulalo, Desa Rumbia dan Desa Botumoito. Sedangkan desa dengan level kesiapan terendah level 7 (stabilitasi) yaitu Desa Tangkobu, Desa Dulangenya dan Desa Hutamonu. Desa Boti dan Desa Tangga Barito berada level 8 (konfirmasi/perluasan). 
Potensi Pengembangan Masoyi (Cryptocarya massoy (Oken) Kosterm) di wilayah UPTD KPH Unit V Boalemo Berdasarkan Kesiapan Masyarakat dan Tingkat Kesesuaian Lahan

Irma Yeny, Budi Hadi Narendra dan Hani Siti Nuroniah

Tabel (Table) 5. Karakteristik lahan pada sebaran alami masoyi di Papua (Land characteristics of masoyi natural distribution in Papua)

\begin{tabular}{|c|c|c|c|}
\hline \multirow[t]{2}{*}{ Variabel (Variables) } & \multicolumn{3}{|c|}{ Sebaran alami masoyi di lokasi penelitian (Natural distribution) } \\
\hline & $\begin{array}{c}\text { Kabupaten } \\
\text { (District) } \\
\text { Bintuni *) }\end{array}$ & $\begin{array}{c}\text { Kabupaten (District) } \\
\text { Nabire } *)\end{array}$ & $\begin{array}{l}\text { Kabupaten (District) } \\
\text { Manokwari**) }\end{array}$ \\
\hline $\begin{array}{l}\text { Elevasi (Elevation) } \\
\text { (m dpl) }\end{array}$ & $300-475$ & $300-450$ & 200 \\
\hline $\begin{array}{l}\text { Kemiringan (Slope) } \\
(\%)\end{array}$ & $2-8$ & $41-60$ & $41-60$ \\
\hline Jenis tanah (Soil type) & $\begin{array}{l}\text { Paleustults, } \\
\text { haplustults }\end{array}$ & $\begin{array}{l}\text { Dystropepts, } \\
\text { humitropepts, } \\
\text { tropaquods }\end{array}$ & $\begin{array}{l}\text { Rendolls, Eutropepts, } \\
\text { Tropudults; } \\
\text { Dystropepts, Tropudalfs }\end{array}$ \\
\hline $\begin{array}{l}\text { Kedalaman efektif } \\
\text { (Depth effectiveness) } \\
(\mathrm{cm})\end{array}$ & $\begin{array}{l}20-60 ; 20- \\
\quad 60\end{array}$ & $20-60 ; 20-60 ; 20-60$ & $\begin{array}{c}20-60 ; 20-60 ; 20-60 \\
20-60\end{array}$ \\
\hline $\begin{array}{l}\text { Kelas tekstur tanah } \\
\text { (Soil texture class) }\end{array}$ & $\begin{array}{l}\text { Moderate } \\
\text { fine (fine) }\end{array}$ & $\begin{array}{l}\text { Medium/mod.fine } \\
\text { Mod.coarse/mod.fine }\end{array}$ & $\begin{array}{l}\text { Med.rock/fine.rock } \\
\text { Mod.fine/fine } \\
\text { Mod.coarse/mod fine }\end{array}$ \\
\hline $\begin{array}{l}\text { Curah hujan } \\
\text { (Precipitation) } \\
(\mathrm{mm} / \mathrm{th})\end{array}$ & $1.300-2.500$ & $>1.800$ & $>2.000$ \\
\hline $\begin{array}{l}\text { Bulan basah (Wet } \\
\text { season) }\end{array}$ & 5 & 7 & 6 \\
\hline $\begin{array}{l}\text { Bulan kering (Dry } \\
\text { season) }\end{array}$ & 3 & 1 & 1 \\
\hline $\begin{array}{l}\text { Suhu min (Min } \\
\text { temperature) }\end{array}$ & 21 & 9 & 16 \\
\hline $\begin{array}{l}\text { Suhu max (Max } \\
\text { temperature) }\end{array}$ & 34 & 30 & 34 \\
\hline
\end{tabular}

Sumber (Source): *) Asmoro, 2016; **) Yeny, \& Minarningsih, 2018

Tabel (Table) 6. Kriteria persyaratan tumbuh masoyi (Masoyi plant growth requirement)

\begin{tabular}{|c|c|c|c|c|}
\hline \multirow{2}{*}{\multicolumn{2}{|c|}{$\begin{array}{c}\text { Variabel } \\
\text { (Variable) }\end{array}$}} & \multicolumn{3}{|c|}{ Kriteria (Criteria) } \\
\hline & & Sesuai (Suitable) & $\begin{array}{c}\text { Agak sesuai } \\
\text { (Moderately } \\
\text { suitable) }\end{array}$ & $\begin{array}{l}\text { Tidak sesuai } \\
\text { (Unsuitable) }\end{array}$ \\
\hline 1 & $\begin{array}{l}\text { Jenis tanah } \\
\text { (Soil type) }\end{array}$ & $\begin{array}{l}\text { Dystropepts; } \\
\text { Humitropepts; } \\
\text { Tropaquods; Paleustults; } \\
\text { Haplustults; Rendolls; } \\
\text { Eutropepts; Tropudults; } \\
\text { Tropudalfs }\end{array}$ & $\begin{array}{l}\text { Terdapat salah } \\
\text { satu jenis tanah } \\
\text { yang sesuai (At } \\
\text { least one suitable } \\
\text { soil type is } \\
\text { available) }\end{array}$ & $\begin{array}{l}\text { Tidak ada } \\
\text { jenis tanah } \\
\text { yang sesuai } \\
\text { (No suitable } \\
\text { soil type) }\end{array}$ \\
\hline 2 & $\begin{array}{l}\text { Tekstur } \\
\text { (Texture) }\end{array}$ & $\begin{array}{l}\text { Moderate fine, moderate } \\
\text { coarse, fine rock }\end{array}$ & $\begin{array}{l}\text { Fine, medium } \\
\text { fine, medium } \\
\text { rock, moderate } \\
\text { rock }\end{array}$ & $\begin{array}{l}\text { Very fine, very } \\
\text { coarse, rock }\end{array}$ \\
\hline 3 & $\begin{array}{l}\text { Kedalaman efektif }(\text { Depth } \\
\text { effectiveness })(\mathrm{cm})\end{array}$ & $>40$ & $20-40$ & $<20$ \\
\hline
\end{tabular}


Tabel (Table) 6. Lanjutan (Continued)

\begin{tabular}{|c|c|c|c|c|}
\hline \multirow{2}{*}{\multicolumn{2}{|c|}{$\begin{array}{l}\text { Variabel } \\
\text { (Variable) }\end{array}$}} & \multicolumn{3}{|c|}{ Kriteria (Criteria) } \\
\hline & & Sesuai (Suitable) & $\begin{array}{c}\text { Agak sesuai } \\
\text { (Moderately } \\
\text { suitable) }\end{array}$ & $\begin{array}{l}\text { Tidak sesuai } \\
\text { (Unsuitable) }\end{array}$ \\
\hline 4 & $\begin{array}{l}\text { Elevasi (Elevation) (m } \\
\text { dpl) }\end{array}$ & $200-500$ & $<200 ; 501-800$ & $>800$ \\
\hline 5 & Kemiringan (Slope) $(\%)$ & $<40$ & $40-60$ & $>60$ \\
\hline 6 & $\begin{array}{l}\text { Curah hujan } \\
\text { (Precipitation) (mm/th) }\end{array}$ & $>2.000$ & $1.300-2.000$ & $<1.300$ \\
\hline 7 & $\begin{array}{l}\text { Jumlah bulan basah (Wet } \\
\text { season) Bulan (Months) }\end{array}$ & $>7$ & $5-7$ & $<5$ \\
\hline 8 & $\begin{array}{l}\text { Jumlah bulan kering } \\
\text { (Dry season)Bulan } \\
\text { (Months) }\end{array}$ & $<3$ & $3-6$ & $>6$ \\
\hline 9 & $\begin{array}{l}\text { Suhu minimum }(\text { Min } \\
\text { temperature })\left({ }^{\circ} \mathrm{C}\right)\end{array}$ & $>16$ & $9-16$ & $<9$ \\
\hline 10 & $\begin{array}{l}\text { Suhu maksimum }(\text { Max } \\
\text { temperature })\left({ }^{\circ} \mathrm{C}\right)\end{array}$ & $32-34$ & $30-31$ & $>34$ \\
\hline
\end{tabular}

Tabel (Table) 7. Rekapitulasi evaluasi kesiapan masyarakat dalam pengembangan tanaman masoyi (Level of community readiness for masoyi plant development)

\begin{tabular}{|c|c|c|c|c|c|c|c|}
\hline No. & $\begin{array}{c}\text { Nama Desa } \\
\text { (village) }\end{array}$ & $\mathrm{A}$ & $\mathrm{B}$ & $\mathrm{C}$ & $\begin{array}{c}\text { Rata-rata skor } \\
\text { (Averagescore } \\
\text { ) }\end{array}$ & $\begin{array}{c}\text { Skor } \\
\text { (Score) }\end{array}$ & Kriteria (Criteria) \\
\hline 1. & Ayululalo & 10 & 7,6 & 10 & 9,20 & 9 & High level \\
\hline 2. & Bendungan & 10 & 8,2 & 10 & 9,40 & 9 & High level \\
\hline 3. & Botumoito & 10 & 7 & 10 & 9,00 & 9 & $\begin{array}{c}\text { High level } \\
\text { Conformation/expan }\end{array}$ \\
\hline 4. & Boti & 10 & 4,9 & 10 & 8,30 & 8 & sion \\
\hline 5. & Dulangenya & 8 & 7 & 8,5 & 7,83 & 7 & Stabilization \\
\hline 6. & Hutamonu & 8 & 7 & 8,5 & 7,83 & 7 & $\begin{array}{c}\text { Stabilization } \\
\text { Conformation/expan }\end{array}$ \\
\hline 7. & Piloliyanga & 10 & 5,5 & 10 & 8,50 & 8 & sion \\
\hline 8. & Rumbia & 10 & 7,6 & 10 & 9,20 & 9 & $\begin{array}{c}\text { High level } \\
\text { Conformation/expan }\end{array}$ \\
\hline 9. & Tangga barito & 10 & 7,6 & 8,5 & 8,70 & 8 & sion \\
\hline 10. & Tangkobu & 8 & 5,5 & 8,5 & 7,33 & 7 & Stabilization \\
\hline
\end{tabular}

Catatan (Remarks): A = Individu (Individu); B = Komunitas (Community); C = Sistem penyampaian (Delivery system)

\section{b. Kesesuaian lahan}

Pertumbuhan tanaman pada dasarnya dipengaruhi oleh faktor internal dari tanaman itu sendiri (genetis dan fisiologis) dan faktor lingkungan (ketersediaan nutrisi, iklim, tanah). Pada penelitian ini, kesesuaian lahan akan dinilai berdasarkan faktor pertumbuhan berupa kondisi tanah dan iklim yang juga merupakan sumberdaya esensial bagi 
pertumbuhan tanaman (Cienciala et al., 2016). Hasil perbandingan antara kondisi lahan pada kawasan hutan produksi UPTD KPH Unit V Boalemo dengan persyaratan tempat tumbuh masoyi seperti tercantum pada Tabel 6, dibagi menjadi tiga kelas yaitu sesuai, agak sesuai, dan tidak sesuai. Hasil species matching dengan bantuan program GIS dituangkan dalam peta kesesuaian jenis masoyi (Gambar 3).

Gambar 3 menunjukkan sebagian besar $31.252,61$ ha $(53,82 \%)$ hutan produksi di wilayah UPTD KPH Unit V Boalemo memiliki kelas agak sesuai dan $17.565,51$ ha $(30,24 \%)$ tidak sesuai. Sedangkan $9.253,30$ ha $(15,93 \%)$ luas hutan produksi memiliki kelas sesuai. Ketiga kelas kesesuaian tersebut terdapat pada lima blok yaitu: 1) blok pemanfaatan HHK-HA, 2) blok HHK-HT, 3) blok pemanfaatan kawasan, jasa lingkungan dan HHBK, 4) blok pemberdayaan masyarakat, dan 5) blok perlindungan. Luas lahan untuk tiap kelas kesesuaian pada masing-masing blok tercantum pada Tabel 8.

Berdasarkan Gambar 3 dan Tabel 8, luasan terbesar dengan kelas sesuai $(64,18 \%)$ dan tidak sesuai $(41,72 \%)$ terdapat pada blok pemanfaatan HHKHA. Untuk kelas agak sesuai, luasan terbesar ada pada blok pemanfaatan kawasan, jasa lingkungan, HHBK $(33,56 \%)$.

Hasil tumpang susun (overlay) antara peta tingkat kesiapan masyarakat di tiap desa dan peta kesesuaian tumbuh jenis masoyi dibagi menjadi tiga tingkatan utama yaitu level 7 (stabilitasi), level 8 (konfirmasi/ perluasan), dan level 9 (rasa memiliki di tingkat masyarakat tinggi). Hasil selengkapnya penilaian tingkat kesesuaian ini dituangkan dalam peta kesesuaian, seperti pada Gambar 4.

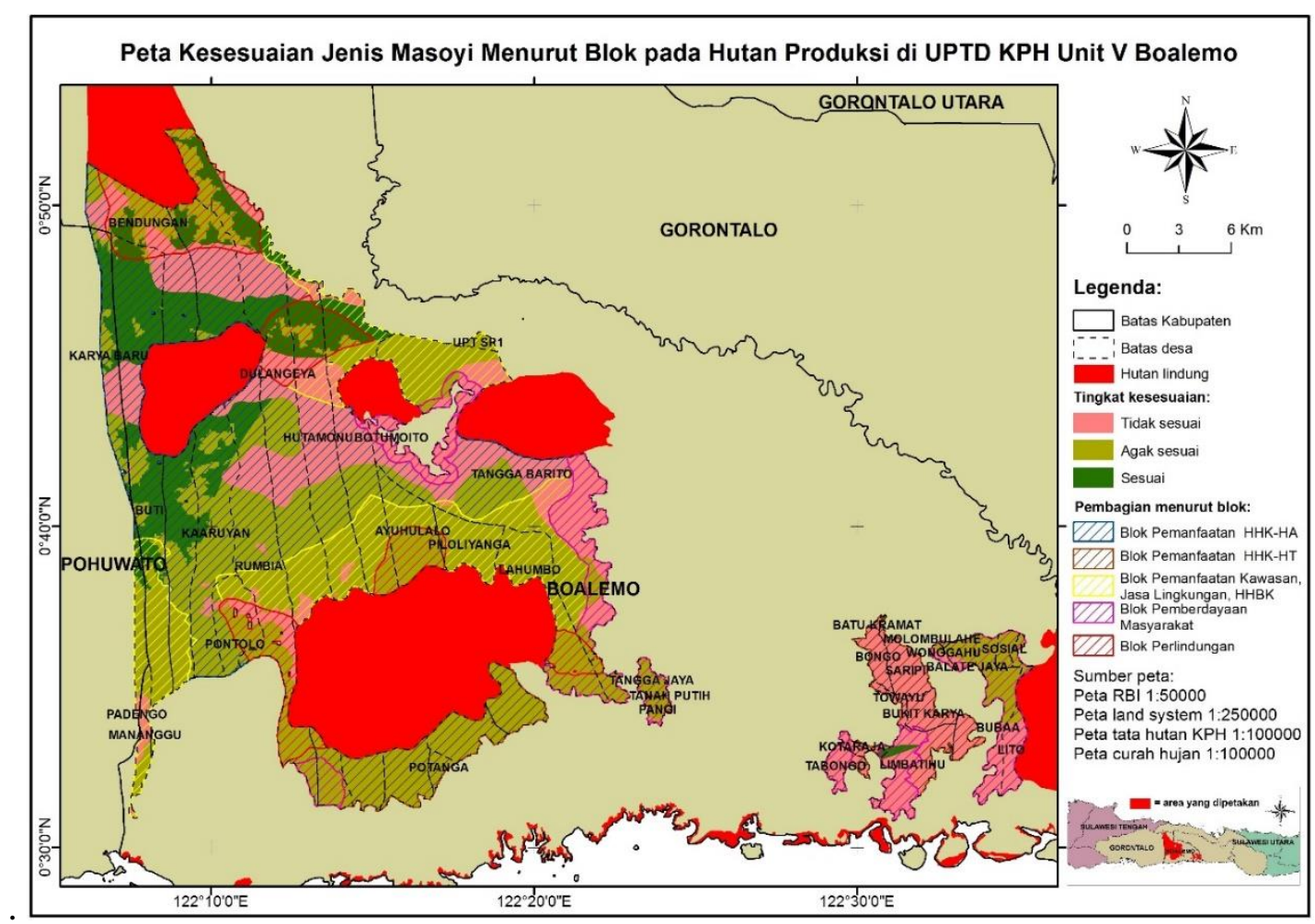

Gambar (Figure) 3. Peta kesesuaian lahan jenis masoyi di kawasan hutan produksi (Land suitability map for masoyi in production forest area) 
Tabel (Table) 8. Kesesuaian tanaman masoyi berdasarkan blok kawasan pada hutan produksi (Masoyi plant suitability based on block division in production forest area)

\begin{tabular}{|c|c|c|c|c|c|c|}
\hline \multirow{3}{*}{$\begin{array}{l}\text { Blok kawasan (Block } \\
\text { region) }\end{array}$} & \multicolumn{6}{|c|}{ Kelas kesesuaian lahan (Land suitability class) } \\
\hline & \multicolumn{2}{|c|}{ Sesuai (Suitable) } & \multicolumn{2}{|c|}{$\begin{array}{c}\text { Agak sesuai } \\
\text { (Moderately suitable) }\end{array}$} & \multicolumn{2}{|c|}{$\begin{array}{l}\text { Tidak sesuai } \\
\text { (Not suitable) }\end{array}$} \\
\hline & $\begin{array}{l}\text { Luas } \\
\text { (Area) } \\
\text { (ha) }\end{array}$ & $\begin{array}{l}\text { Persen } \\
(\%)\end{array}$ & $\begin{array}{l}\text { Luas } \\
\text { (Area) } \\
\text { (ha) }\end{array}$ & $\begin{array}{l}\text { Persen } \\
(\%)\end{array}$ & $\begin{array}{l}\text { Luas } \\
\text { (Area) } \\
\text { (ha) }\end{array}$ & $\begin{array}{l}\text { Persen } \\
(\%)\end{array}$ \\
\hline $\begin{array}{l}\text { Blok pemanfaatan HHK-HA } \\
\text { (Utilization block-NTF's } \\
\text { natural forest) }\end{array}$ & $5.939,22$ & 64,18 & $9.444,24$ & 30,22 & $7.328,61$ & 41,72 \\
\hline $\begin{array}{l}\text { Blok pemanfaatan HHK-HT } \\
\text { (Utilization block-NTF's } \\
\text { plantation forest) }\end{array}$ & 15,53 & 0,17 & $3.473,19$ & 11,11 & $2.472,02$ & 14,07 \\
\hline $\begin{array}{l}\text { Blok pemanfaatan kawasan, } \\
\text { jasa lingkungan, HHBK } \\
\text { (Utilization } \\
\text { zone,environmental } \\
\text { services, } N T F P \text { ) }\end{array}$ & 814,47 & 8,80 & $10.488,00$ & 33,56 & $1.936,58$ & 11,02 \\
\hline $\begin{array}{l}\text { Blok pemberdayaan } \\
\text { masyarakat (Community } \\
\text { empowerment block) }\end{array}$ & 98,19 & 1,06 & $3.166,73$ & 10,13 & $4.263,32$ & 24,27 \\
\hline $\begin{array}{l}\text { Blok perlindungan } \\
\text { (Shelter block) }\end{array}$ & $2.385,90$ & 25,78 & $4.680,45$ & 14,98 & $1.564,98$ & 8,91 \\
\hline Total & $9.253,30$ & 100,00 & $31.252,61$ & 100,00 & $1.7565,51$ & 100,00 \\
\hline
\end{tabular}

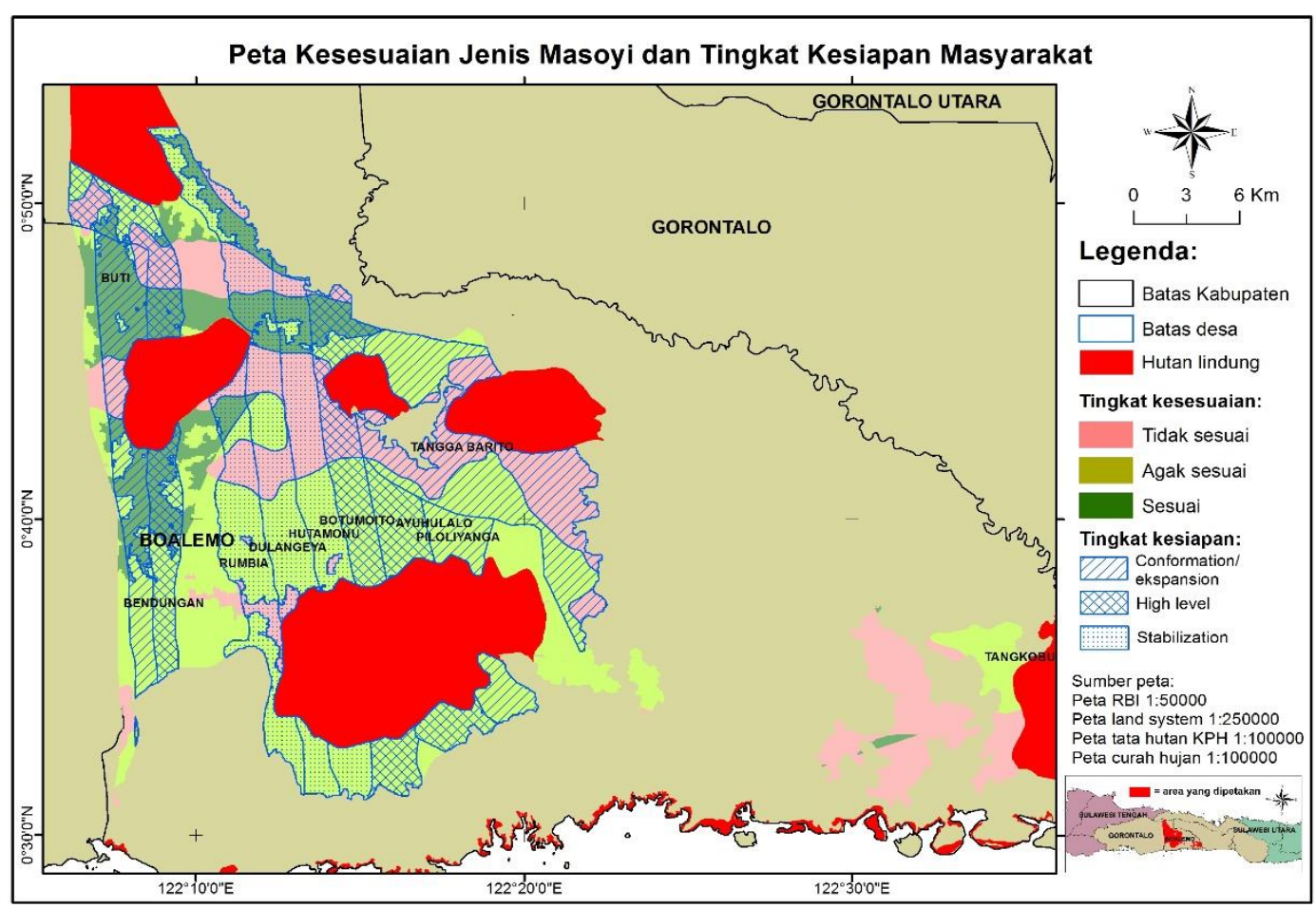

Gambar (Figure) 4. Peta kesesuaian pengembangan masoyi di UPTD KPH Unit V Boalemo (Suitability map for masoyi development in Boalemo) 
Gambar 4 menunjukkan wilayah dengan tingkat kesiapan masyarakat level 9 (rasa memiliki di tingkat masyarakat tinggi) sebagian besar memiliki tingkat kesesuaian lahan pada kategori agak sesuai $(62,39 \%)$. Sedangkan wilayah dengan tingkat kesiapan masyarakat level 9 (rasa memiliki di tingkat masyarakat tinggi) dan tingkat kesesuaian lahan pada kategori sesuai seluas 2.277 ha $(20,74 \%)$ yang terletak pada Desa Bendungan (1.611 ha) dan Desa Botumoito (666 ha) (Tabel 9).

Pada Tabel 9 terlihat bahwa wilayah dengan tingkat kesiapan masyarakat yang tinggi baik level 7 sampai dengan 9, namun memiliki kelas kesesuaian lahan tidak sesuai berada di delapan dari sepuluh desa tersebut dengan total luasan 11.454 ha. Pada lahan tersebut tidak disarankan sebagai wilayah pengem-bangan masoyi walaupun kesiapan ma-syarakat pada wilayah ini cukup tinggi. Wilayah dengan tingkat kesiapan masya-rakat yang tinggi baik level 7 sampai dengan 9 namun memiliki kelas kesesuaian agak sesuai dengan luas 22.644 ha, berpeluang menjadi wilayah pengembangan masoyi. Sementara itu 7.041 ha lahan menjadi lahan priototas bagi pengembangan masoyi yang didukung oleh tingkat kesiapan masyarakat yang tinggi.

Tabel (Table) 9. Prioritas luas wilayah (ha) pengembangan masoyi berdasarkan tingkat kesiapan masyarakat dan kesesuaian lahan (Priority area (ha) for masoyi plant development based on community readiness level and land suitability)

\begin{tabular}{|c|c|c|c|c|c|c|c|c|c|}
\hline \multirow{4}{*}{$\begin{array}{c}\text { Desa } \\
\text { (Village) }\end{array}$} & \multicolumn{9}{|c|}{ Kesesuaian lahan (Land suitability) } \\
\hline & \multicolumn{3}{|c|}{$\begin{array}{c}\text { Sesuai } \\
\text { (Suitable) }\end{array}$} & \multicolumn{3}{|c|}{$\begin{array}{c}\text { Agak sesuai (Moderately } \\
\text { suitable) }\end{array}$} & \multicolumn{3}{|c|}{$\begin{array}{l}\text { Tidak sesuai } \\
\text { (Unsuitable) }\end{array}$} \\
\hline & \multicolumn{9}{|c|}{ Level kesiapan masyarakat (Community readiness level) } \\
\hline & 9 & 8 & 7 & 9 & 8 & 7 & 9 & 8 & 7 \\
\hline Ayululalo & - & - & - & 2.184 & - & - & 3 & - & - \\
\hline Bendungan & $\begin{array}{c}1.61 \\
1\end{array}$ & - & - & 2.040 & - & - & 948 & - & - \\
\hline Botumoito & 6.66 & - & - & 2.627 & - & - & 902 & - & - \\
\hline Boti & - & $\begin{array}{c}2.50 \\
3\end{array}$ & - & - & 1.459 & - & - & 575 & - \\
\hline Dulangenya & - & - & $\begin{array}{c}1.40 \\
6\end{array}$ & - & - & 3.265 & - & - & 2.019 \\
\hline Hutamonu & - & - & 561 & - & - & 2.053 & - & - & 1.609 \\
\hline Piloliyanga & - & - & - & - & 1.812 & - & - & - & - \\
\hline Rumbia & - & - & 290 & - & - & 2.941 & - & - & 1.028 \\
\hline Tanggabarito & - & 4 & - & - & 4.262 & - & - & 4370 & - \\
\hline Tangkobu & - & - & - & - & - & 1 & - & - & - \\
\hline & 2.27 & 2.50 & 2.25 & & & & & & \\
\hline Total & 7 & 7 & 7 & 6.851 & 7.533 & 8.260 & 1.853 & 4.945 & 4.656 \\
\hline
\end{tabular}

\section{B. Pembahasan}

Potensi pengembangan masoyi di UPTD KPH Unit V Boalemo diukur melalui sumberdaya manusia (kesiapan masyarakat) dan sumberdaya lahan (kesesuaian lahan). Possumah et al. (2015) menyebutkan dalam rencana pembangunan $\mathrm{HKm}$ di Desa Kilo Kecamatan Poso 
Pesisir Utara Kabupaten Poso, salah satu faktor yang paling berpengaruh dalam pengelolaan $\mathrm{HKm}$ adalah kesiapan masyarakat. Lebih lanjut dikatakan bahwa presepsi dan sikap masyarakat dapat dipandang sebagai bentuk kesiapan masyarakat dalam pengembangan hutan kemasyarakatan (HKm). Sementara itu Plested et al. (2006) mengembangkan tingkat kesiapan masyarakat dengan memadukan budaya masyarakat dan sumberdaya, sehingga menghasilkan efektivitas dalam menangani suatu masalah.

Berdasarkan tingkat kesiapan masyarakat yang dikembangkan Plested et al. (2006), terdapat sepuluh desa yang memiliki kesiapan masyarakat dengan level tertinggi 9 dan level terendah 7 . Level kesiapan masyarakat tertinggi yaitu (level 9) terdapat di Desa Ayuhulalo, Bendungan, Baotumoito, Rumbia dan level kesiapan masyarakat terendah level 7 yaitu Desa Dulangenya, Hutamonu, Tangkobu. Pada desa dengan kesiapan level 9 tersebut menunjukkan 1) pembinaan masyarakat dalam pengembangan masoyi telah dilakukan, 2) terdapat masyarakat yang terlatih dalam pengembangan masoyi, 3) evaluasi dalam memperbaiki dan mengembangkan program pengembangan masoyi telah berjalan. Kondisi ini terlihat pada interaksi sosial antara KPH dengan masyarakat cukup tinggi sehingga secara sosial program dan kebijakan KPH lebih mudah diterima oleh masyarakat. Hal ini sejalan dengan pendapat Hidayah (2011) yang mengatakan bahwa dengan adanya kesiapan secara psikologis, maka seseorang akan mampu menyelesaikan suatu pekerjaan sesuai harapan sehingga dapat mencapai hasil yang maksimal. Kesiapan masyarakat pada kondisi level 7 menunjukkan bahwa 1) program, kegiatan dan kebijakan pengelolaan hutan belum banyak disampaikan, sehingga masyarakat tidak tertarik untuk merespon pengembangan komoditas masoyi; 2) telah terbentuk komunitas yang terlatih dan berpengalaman dalam budidaya tanaman, namun presepsi masyarakat untuk merubah komoditi yang dibudidayakan dari komoditi jagung ke komoditi masoyi masih rendah; 3) belum terdapat program evaluasi terhadap efektivitas program pengembangan masoyi diwilayah tersebut. Kondisi ini diduga terjadi karena hanya sebagian kecil luas wilayah desa yang masuk wilayah $\mathrm{KPH}$, sehingga belum banyak aktivitas dan pembinaan yang dilakukan bersama KPH. Hal ini menunjukkan bahwa kesiapan masyarakat dalam mengembangkan masoyi sangat bergantung pada program kerja KPH Boalemo. Oleh karena itu, untuk memperoleh nilai kesiapan masyarakat yang tinggi perlu adanya interaksi intesif antara masyarakat dan KPH.

Nilai kesiapan masyarakat pada beberapa desa menunjukkan telah terjadi interaksi sosial yang baik antara masyarakat, pemerintah desa dan pengelola hutan. Interaksi sosial terjadi karena adanya kontak sosial dan komunikasi. Kontak sosial terlihat pada adanya tanggapan akan tindakan pengelolaan hutan; sedangkan komunikasi terlihat pada adanya penafsiran yang sama pada suatu perilaku ketiga pihak tersebut.

Hasil analisis kesesuaian lahan secara matching antara persyaratan tumbuh masoyi dengan karakteristik lahan di Boalemo menunjukkan bahwa wilayah terluas yang karakteristik lahannya paling sesuai untuk tanaman masoyi berada di dalam blok pemanfaatan HHK-HA, terutama pada bagian barat dan utara yang meliputi Desa Buti, Desa Bendungan, dan sebagian Desa Dulangeya. Hal sebaliknya, lahan terluas yang tidak sesuai untuk masoyi juga terletak dalam blok 
pemanfaatan HHK-HA tepatnya di bagian tengah dan timur, mencakup wilayah Desa Tangga Barito, sebagian Desa Dulangeya, dan Hutamonu.

Hasil analisis klasifikasi kesesuaian lahan tersebut menunjukkan sejumlah wilayah tidak sesuai untuk ditanami masoyi dikarenakan adanya faktor penghambat terutama berupa jumlah bulan basah, curah hujan tahunan, suhu maksimum, elevasi, dan kemiringan lereng (slope). Pada penelitian ini, faktor pembatas curah hujan tahunan banyak dialami di Kecamatan Paguyaman Pantai dengan curah hujan kurang dari yang dipersyaratkan (1.300 mm/tahun). Jumlah bulan basah juga menjadi faktor penghambat karena beberapa area hanya memiliki empat bulan basah dari minimal lima bulan yang dipersyaratkan. Elevasi juga menjadi faktor penghambat karena sebagian area di Kecamatan Botumoito dan Mananggu memiliki ketinggian 1.100 m dpl, sedangkan persyaratan maksimal ketinggian untuk tumbuh tanaman masoyi adalah $800 \mathrm{~m}$ dpl. Faktor pembatas berupa kemiringan lereng, banyak dijumpai pada area di Kecamatan Botumoito, Dulupi, dan Mananggu karena area ini memiliki kemiringan lereng lebih dari $60 \%$. Curah hujan, suhu udara, dan kelembaban tanah merupakan faktor krusial bagi pertumbuhan tanaman (Sun, \& Liu, 2016). Kurangnya curah hujan maupun distribusi bulanan curah hujan yang tidak mencukupi akan mengakibatkan cekaman kekeringan, berpengaruh secara signifikan terhadap proses fenologi pembungaan, penurunan biomasa, penurunan pertumbuhan tinggi batang dan luas tajuk pohon (Podlesny, \& Podlesna, 2011; Zeppel, JV, \& JD, 2014). Suhu harian maksimum yang melewati batas toleransi juga dapat menghambat pertumbuhan pohon karena adanya peningkatan respirasi, menurunnya fotosintesis, gangguan terhadap fungsi stomata (Schippers, Sterck, Vlam, \& Zuidema, 2015), dan proses reproduksi tanaman (Hatfield, \& Prueger, 2015). Elevasi yang tidak sesuai juga menjadi faktor penghambat bagi pertumbuhan tinggi, diameter dan volume batang tanaman (Ndema, \& Missanjo, 2015). Perbedaan elevasi antar tempat akan berpengaruh terhadap perbedaan tekanan, suhu dan kelembaban udara. Di Indonesia umumnya setiap kenaikan $100 \mathrm{~m}$ akan menurunkan suhu maksimum udara $0,6^{\circ} \mathrm{C}$ sedangkan suhu minimumnya turun $0.5^{\circ} \mathrm{C}$ (Massinai, Hasanah, \& Nuryati., 2013). Faktor elevasi ini yang juga mempengaruhi curah hujan, kecepatan angin, dan karakteristik tanah (Sundqvist, Sanders, \& Wardle, 2013; Mayor et al., 2017) yang pada akhirnya akan mempengaruhi pertumbuhan dan produksi tanaman.

Kemiringan lereng yang melebihi persyaratan pada tanaman tertentu dapat berpengaruh secara langsung maupun tidak langsung. Tanaman yang tumbuh di lereng curam, cenderung memiliki arsitektur akar yang tidak seimbang. Kondisi ini juga mengakibatkan adanya perubahan secara anatomi terhadap bentuk dan susunan jaringan akar, jika dibandingkan dengan tanaman yang tumbuh normal di tempat lebih datar. Peningkatan kemiringan lereng juga berkorelasi negatif terhadap pertumbuhan tinggi dan diameter batang tanaman (Gebretsadik, 2012), serta produksi tanaman (Andrian, Supriadi, \& Marpaung, 2014). Hal ini terkait dengan adanya penurunan kesuburan tanah akibat erosi. Proses erosi akan meluruhkan partikel tanah, nutrisi dan bahan organik, serta mempengaruhi struktur tanah, porositas, dan kemampuan menyimpan air 
(Espigares, Heras, \& Nicolau, 2011). Tanaman yang berada pada lereng bagian atas dan tengah akan cenderung memiliki pertumbuhan yang lebih lambat dibandingkan pada lereng bawah karena pada bagian tersebut lapisan tanah yang subur cenderung makin tipis akibat erosi (Tuo Xu, \& Gao, 2018)

Faktor bulan basah, curah hujan, dan suhu maksimum merupakan unsur iklim yang sulit diperbaiki karena sifatnya yang cenderung permanen (Widiatmaka, Sutandi, Iswandi, Daras, Hikmat, Krisnohadi, 2014). Demikian pula dengan faktor elevasi yang pengaruhnya identik dengan pengaruh iklim, akan sangat sulit untuk mengubahnya. Faktor penghambat berupa kemiringan lereng, biasanya diminimalkan dengan penerapan teknik konservasi tanah guna menurunkan kemiringan lereng seperti pembuatan teras bangku, meskipun dalam penerapannya perlu mempertimbangkan aspek ekonomi.

\section{KESIMPULAN DAN SARAN}

\section{A. Kesimpulan}

Analisis kesiapan masyarakat pada sepuluh desa yang diuji menunjukkan nilai kesiapan yang tinggi yaitu level 7 sampai dengan level 9. Nilai ini menunjukkan terdapatnya kesepahaman masyarakat dalam pengelolaan hutan khususnya dalam program pengembangan masoyi. Sementara itu analisis kesesuaian lahan menunjukkan sebagian besar $(53,82 \%)$ hutan produksi di wilayah UPTD KPH Unit V Boalemo memiliki kelas agak sesuai, $17.565,51$ ha $(30,24 \%)$ tidak sesuai dan $9.253,30$ ha $(15,93 \%)$ memiliki kelas sesuai. Berdasarkan analisis kesiapan masyarakat pada sepuluh desa dan kesesuaian lahan di hutan produksi terdapat 29.685 ha wilayah yang potensial dan menjadi prioritas pengembangan masoyi. Desa dengan tingkat kesiapan masyarakat terbaik dan kesesuaian lahan pada kriteria sesuai adalah Desa Bendungan dan Desa Butomoito.

\section{B. Saran}

Pada lahan dengan tingkat kesiapan masyarakat tinggi namun kesesuaian lahan agak sesuai dapat dilakukan pengembangan masoyi dengan melakukan perbaikan/manipulasi lahan terhadap faktor pembatas (jumlah bulan basah, curah hujan tahunan, suhu maksimum, elevasi, dan kemiringan lereng (slope) guna mendukung keberhasilan penanaman.

Analisis kesiapan masyarakat dan tingkat kesesuaian lahan pengembangan masoyi perlu dilakukan di wilayah Indonesia sebagai upaya mendukung berkembangnya penyediaan bahan baku industri minyak atsiri jenis masoyi di Indonesia.

\section{UCAPAN TERIMA KASIH}

Penelitian ini dibiayai DIPA APBN Pusat Penelitian dan Pengembangan Hutan tahun anggaran 2015. Terima kasih disampaikan kepada Ir. Djimlan (Kepala UPTD KPH Unit V Boalemo), Kepala Desa Bandungan, Kepala Desa Ayuhulalo atas data dan informasi yang diberikan selama penelitian berlangsung. Ucapan terima kasih juga disampaikan pada Faturahman, S.Hut, Ari S,Hut dan Irwan atas bantuannya selama penelitian berlangsung.

\section{DAFTAR PUSTAKA}

Andrian, Supriadi, \& Marpaung, P. (2014). Pengaruh ketinggian tempat dan kemiringan lereng terhadap produksi karet (Hevea brasiliensis Muell.Arg.) di Kebun Hapesong 
PTPN III Tapanuli Selatan. Agroekoteknologi, 2(3), 981-989.

Asmoro, J.P. (2016). Spatial analysis massoia (Cryptocarya massoia (Oken) Kosterm distribution in Papua. In IUFRO Regional Congres for asia and oceania (p. 361). China National Convention Centre, Bejing, China: IUFRO.

Bustanussalam, Haryanto, S., \& Endang, N. (2014). Identifikasi senyawa dan uji aktivitas ekstrak etil asetat kulit kayu masoyi. Jurnal Fitofarmaka, 14(2), 152-168.

Cienciala, E., Russ, R., Šantrůčková, H., Altman, J., Kopáček, J., Hůnová, I., Štěpánek, O., Oulehle, F., Tumajer, J., Ståhl, G. (2016). Discerning environmental factors affecting current tree growth in Central Europe. Science of the Total Environment, 573, 541-554. http:// dx.doi.org/10.1016/j.scitotenv.2016 .08 .115 .

Elaalem, M., Comber, A., \& Fisher, P. (2011). A comparison of fuzzy AHP and ideal point methods for evaluating land suitability. Transactions in GIS, 15(3), 329346. http://doi.org/10.1111/j.14679671.2011.01260.x

Elsheikh, R, Shariff, A.R.B.M., Amiri, F., Ahmad, N.B., Balasundram, S.K., \& Soom, M.A.M. (2013). Agriculture land suitability evaluator (ALSE): A decision and planning support tool for tropical and subtropical crops. Computers and Electronics in Agriculture 93: 98-110. doi: 10.1016/j.compag.2013.02.003.

Espigares, T., Heras, M.M., Nicolau, J.M. (2011). Performance of vegetation in reclaimed slopes affected by soil erosion. Restorotation Ecology 19(1): 35-44. doi: 10.1111/j.1526-
100X.2009.00546.X

Gebretsadik, Z.M. (2012). The effect of slope on diameter and height growth of grevillea robusta at Wondo Genet, Southern Ethiopia. The African Journal of Plant Science and Biotechnology, 6(1), 76-79.

Hatfield, J., \& Prueger, H. (2015). Temperature extremes: effect on plant growth and development. Weather and Climate Extremes. Weather and Climate Extremes, 10, 4-10.

http://doi.org/10.1016/j.wace.2015. 08.001 .

Hidayah, N. (2011). Kesiapan psikologis masyarakat pedesaan dan perkotaan menghadapi diversivikasi pangan pokok. Humanitas, 8(1), 88-104.

Kawy, W., \& El-Magd, I. (2012). Use of satellite data and GIS for assessing the agricultural potentiality of the soils South Farafra Oasis Western Desert, Egypt. Arabian Journal of Geosciences, 6(7), 2299-2311. http://doi.org/10.1007/s12517-0120518-5.

Kazemi. H., \& Akinci, H. (2018). A land use suitability model for rainfed farming by multi-criteria decision making analysis (MCDA) and Geographic Information System (GIS). Ecological Engineering 116: 1-6. doi: 10.1016/j.ecoleng.2018. 02.021 .

Massinai, M.A., Hasanah, N., \& Nuryati. (2013). Analisis kecenderungan perubahan suhu udara permukaan Kota Makassar. Prosiding Seminar Nasional Fisika. Jurusan Fisika, FMIPA Universitas Hasanuddin, Makassar.

Mayor, J., Sanders, N., Classen, A., Bardgett, R., Clément, J., Fajardo, A., Wardle, D. (2017). Elevation 
alters ecosystem properties across temperate tree lines globally. Nature, 542(7639), 91-95. http://doi.org/10.1038/nature21027.

Mokarram, M., \& Aminzadeh, F. (2010). GIS-based multi-criteria land suitability evaluation using ordered weight averaging with fuzzy quantifier: a case study in Shavur Plain, Iran. The International Archives of the Photogrammetry, Remote Sensing and Spatial Information Sciences, 38(2), 508512.

Ndema, A., \& Missanjo, E. (2015). Tree growth response of pinus oocarpa along different altitude in Dedza Mountain forest plantation. Agriculture, Forestry and Fisheries, $4(1), \quad 24-28 . \quad$ http://doi.org/ 10.11648/j.aff.20150401.15.

Pan, G., \& Pan, J. (2012). Research in crop land suitability analysis based on GIS. Computer and Computing Technologies in Agriculture, 365, 314-325. http://doi.org/10.1007/ 978-3-642-27278-3_33.

Plested, B.A., Edwards, R.W., \& Jumper, T.P. (2006). Community readiness:a handbook for succesful change. Colorado state university: The ethnic center for prevention research.

Podleśny, J., \& Podleśna, A. (2011). Effect of rainfall amount and distribution on growth, development and yields of determinate and indeterminate cultivars of blue lupin. Polish Journal of Agronomy, 4, 16-22.

Possumah, I., Golar, \& Toknok, B. (2015). Kesiapan masyarakat terhadap pembangunan hutan kemasyarakatan di Desa Poso Pesisir Utara. Warta Rimba, 3(2), 124-131.
Rhebergen, T., Fairhurst, T., Zingore, S., Fisher, M., Oberthür, T., \& Whitbread, A. (2016). Climate, soil and land-use based land suitability evaluation for oil palm production in Ghana. European Journal of Agronomy, 81, 1-14. http://doi.org/ 10.1016/j.eja.2016.08.004.

Rostiwati, T., \& Efendi, R. (2013). Mendulang uang tanpa tebang, Lima jenis HHBK unggulan. (G. Pari \& P. Setio, Eds.). Bogor: Forda Press.

Schippers, P., Sterck, F., Vlam, M., \& Zuidema, P. (2015). Tree growth variation in the tropical forest: understanding effects of temperature, rainfall and $\mathrm{CO} 2$. Global Change Biology, 21, 27492761. http://doi.org/10.1111/ gcb. 12877 .

Suminar, S., Arifin, B., \& Kemala, T. (2015). Naskah akademik membangun standar nasional Indonesia untuk komoditas minyak masoyi.

Sun. C., \& Liu, Y. (2016). Climate response of tree radial growth at different time scales in the Qinling Mountains. PLoS ONE, 11(8), e0160938. http://doi.org/10.1371/ journal.pone.0160938.

Sundqvist, M.K., Sanders, N.J., Wardle, D.A. (2013). Community and ecosystem responses to elevational gradients: processes, mechanisms, and insights for global change. The Annual Review of Ecology, Evolution, and Systematics 44: 261 80. doi: 10.1146/annurev-ecolsys110512-135750.

Tuo, D., Xu, M., \& Gao, G. (2018). Relative contributions of wind and water erosion to total soil loss and its effect on soil properties in sloping croplands of the Chinese Loess Plateau. Science of the Total 
Environment, 633, 1032-1040. http://doi.org/10.1016/j.scitotenv.20 18.03.237.

UPTD KPH Unit V Boalemo. (2015). Rencana pengelolaan hutan jangka panjang. Gorontalo.

Widiatmaka, Sutandi, A., Iswandi. A., Daras. U., Hikmat, M., Krisnohadi, A. (2014). Establishing land suitability criteria for cashew (Anacardium occidentale L.) in Indonesia. Applied and Environmental Soil Scienc, 2014, 114. http://doi.org/10.1155/2014/ 743194.

Wijaya, E., \& Wiryawan, B.A. (2013). Hambatan kesiapan masyarakat Desa Sei dalam pembangunan canal bloking pada rawa gambut. Jurnal Sosek Pekerjaan Umum, 5(3), 140216.
Yeny, I., \& Minarningsih. (2018). Potensi dan peluang pengembangan Cryptocarya massoy Oken Konstrem untuk kesejahteraan masyarakat dan kelestarian keragaman hayati. In I. Tobing \& I. Matondang (Eds.), Prosiding SemNas "Biodiversitas Untuk Kehidupan” (pp. 372-387). Jakarta: Pusat Penelitian dan Pengembangan Tumbuhan Obat, Pusat Kajian Lingkungan dan Konservasi Alam, Fakultas Biologi Universitas Nasional.

Zeppel, M.J.B, JV, W., \& JD, L. (2014). Impacts of extreme precipitation and seasonal changes in precipitation on plants. Biogeosciences, 11, 3083-3093. http://doi.org/10.5194/bg-11-30832014. 